Volume 8. No. 8, August 2020

International Journal of Emerging Trends in Engineering Research

Available Online at http://www.warse.org/IJETER/static/pdf/file/ijeter118882020.pdf

https://doi.org/10.30534/ijeter/2020/118882020

\title{
The Application of Coffee Grinding Machine to increase the Production Capacity of Temanggung Coffee
}

\author{
Vivi Endar Herawati ${ }^{1}$, Lintan Dian Saraswati $^{2}$, Muhammad Arfan ${ }^{3}$, Gilar Pandu Annanto ${ }^{3}$, Rahmat \\ Mafuh Ihsan ${ }^{3}$ \\ ${ }^{1}$ Faculty of Marine, Universitas Diponegoro, Semarang 50275, Indonesia \\ ${ }^{2}$ Faculty of Health, Universitas Diponegoro, Semarang 50275, Indonesia \\ ${ }^{3}$ Faculty of Engineering, Universitas Diponegoro, Semarang 50275, Indonesia \\ *Corresponding email: anshinvie@yahoo.com
}

\begin{abstract}
Coffee (Coffea arabica) is a genus of flowering plants whose seeds, called coffee beans, are used to make coffee drink. it is a member of the Rubiaceae family. Coffee is an important commodity, especially for Indonesia, this is because coffee become one of biggest revenue for the country. One of the coffee production centres was in central java with temanggung become the most productive district in its. the production robusta coffee reach $30.27 \%$ and the arabica coffee reach $22.16 \%$. Despite of it, the production capacity of in temanggung district is still lower that its potential. Based on the research, the production level of temanggung coffee can reach 1.3 ton of robusta coffee per hectar are and for the arabica coffee can reach 1.4 ton per hectar are. The reason of why the production level below its potential is because most of the people who work in the temanggung coffee industry are limited to the technology to increase the production level. One the problem that faced the farmer is the grinding process, the common grinding machine are able to grind $200 \mathrm{gr}$ of coffee in one time and need to be rested for 5 minutes to grind another bean. Due to this problem, a customized grinding machine were applicated. The current machine can perform up to $52 \mathrm{~kg}$ per hour compared to the common machine that only can perform up to $5 \mathrm{~kg}$ per hour.
\end{abstract}

Key words : Coffea arabica, Coffea robusta, Grinding process, Important commodity, Productivity

\section{INTRODUCTION}

Coffee (Coffea arabica) is a genus of flowering plants whose seeds, called coffee beans, are used to make coffee drink. it is a member of the Rubiaceae family. They are evergreen shrubs or small trees that grow approximately $5 \mathrm{~m}(15 \mathrm{ft})$ tall when unpruned. Coffee trees are native to tropical Asia and Southern Africa. Coffee ranks as one of the world's most valuable and widely traded commodity crops and is an important export product of several countries [1]. The leaves are dark green and glossy, usually $10-15 \mathrm{~cm}$ (4-6 in) long and $6 \mathrm{~cm}$ (2.4 in) wide. The flowers are axillary, and clusters of fragrant white flowers bloom simultaneously and are followed by oval berries of about $1.5 \mathrm{~cm}$ (0.6 in). Green when immature, they ripen to yellow, then crimson, before turning black on drying. Each berry usually contains two seeds, but $5-10 \%$ of the berries have only one; these are called pea berries. Berries ripen in seven to nine months [2]. Coffea arabica is predominantly self-pollinating and as a result, the seedlings are generally uniform and vary little from their parents. In contrast, Coffea canephora, C. excelsa, and C. liberica are self-incompatible and require outcrossing. This means that useful forms and hybrids must be propagated vegetative. Cuttings, grafting, and budding are the usual methods of vegetative propagation. On the other hand, there is great scope for experimentation in search of potential new strains [3].

Coffee is an important commodity, especially for Indonesia, this is because coffee become one of biggest revenue for the country [4]. Based on the data from Agriculture ministry on 2015, export value of coffee reaches USD 45 million [5]. Because of this, coffee become an opportunity for more than 5 million people who work in this commodity [6]. Almost 70\% of the coffee produced in Indonesia were exported to many countries and only $30 \%$ that consumed in Indonesia itself. In central java, the volume of coffee that going to export are reach more than 10 thousand ton and has value more than 9.5 million USD.

The center of coffee production in central java was located in Temanggung district, Semarang district, Kendal, Jepara and Wonosobo, Banjarnegara, Klaten, Pemalang, and many more. Table 1 show the percentage of the production in every district.

From the table 1, it can be seen that Temanggung become the most productive district in central java with the production robusta coffee reach $30.27 \%$ and the arabica coffee reach $22.16 \%$. Despite of it, the production capacity of in 
temanggung district is still lower that its potential. Based on the research, the production level of temanggung coffee can reach 1.3 ton of robusta coffee per hectare are and for the arabica coffee can reach 1.4 ton per hectare are. One of the reasons that makes the production level below its potential is because most of the people who work in the temanggung coffee industry are limited to the technology to increase the production level [7]. Besides that, the plantation technic that applicated by the farmer still improper and does not fit with the good agriculture practice [8].

Table 1: The percentage of total coffee production in central java

\begin{tabular}{|c|c|c|}
\hline District & $\begin{array}{c}\text { Production of } \\
\text { robusta }\end{array}$ & $\begin{array}{c}\text { Production of } \\
\text { robusta }\end{array}$ \\
\hline Temanggung & $30.27 \%$ & $22.16 \%$ \\
\hline Semarang & $10.86 \%$ & - \\
\hline Kendal & $8.69 \%$ & - \\
\hline Jepara & $7.67 \%$ & - \\
\hline Wonosobo & $6.06 \%$ & $15.1 \%$ \\
\hline Banjarnegara & - & $10.23 \%$ \\
\hline Klaten & - & $9.03 \%$ \\
\hline Pemalang & - & $8.06 \%$ \\
\hline
\end{tabular}

Due to this problem, this paper was focus to improve the production capacity of the Temanggung coffee so it can reach the potential value. One the problem that faced the farmer is the grinding process. The coffee bean needs to grind in to powder. The common grinding machine that used by the farmer has a low capacity of grinding. The common grinding machine are able to grind $200 \mathrm{gr}$ of coffee in one time and need to be rested for 5 minutes to grind another bean. The resting time needed because the common grinding machine will produce excessive heat in its motor and when it does not cool down, the potential breakdown is high. Due to this problem, an application of customized grinding machine will be expected to improve the production capacity of the coffee.

For improving integration and development the previous works of other research can be considered [9] [10].

\section{MATERIALS AND METHOD}

\subsection{Material Selection}

The materials used were obtained locally at Semarang, Central java, the materials were critically considered based on strength, availability, durability and corrosiveness to prevent machine damage, ease construction work and maintenance and prevent rusting or corrosion of the machine parts hence, mild steel angle iron was used for the frame and stainless steel for the disk mill housing.

\subsection{Design Consideration and Analysis}

The predesign stage included measurement of the physical and engineering properties of the crop to determine appropriate design parameters for the grinder operation. The decorticating and separation component were designed using relevant engineering principles and theories. The design concept involves the use of impact and frictional forces of rubber beaters against steel plate, lined with reinforced rubber strip to reduce crop breakage with reasonable power requirement. The design considerations included use of gravity and minimum friction to reduce power requirement, economy and ergonomics, machine efficiency and product quality, simple operational and maintenance requirements to meet the need of local farmers and small-scale industrialist, portability and detachability for easy transportation and low grain damage.

\subsection{Component Parts of the machine}

The grinder machine could be divided into 4 major units: Customized Disk blade, frames, electric motor, and hopper. The detail of the component can be seen on the Figure 1

\section{A. Hoper}

The Hopper has the function to accommodate the coffee bean before it will be crushed. The hopper can handle up to $5 \mathrm{~kg}$ of coffee bean in one time of grinding process. When the coffee bean poured into the hopper, it will direct the coffee bean into the crusher area or the disk area. Using hopper can increase the effectiveness of the machine, because of its capacity to hold up to $5 \mathrm{~kg}$ of bean, the farmer can do the job faster. The hopper design can be seen on Figure 1

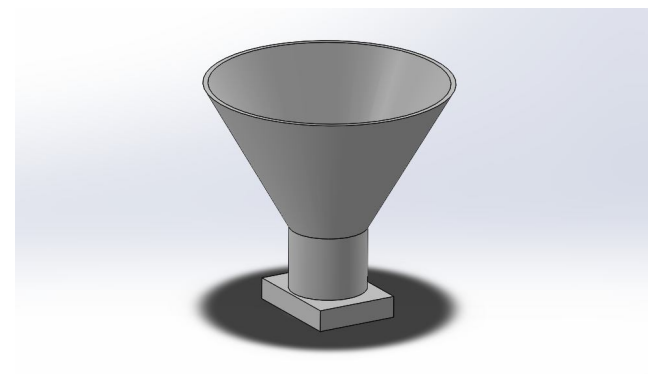

Figure 1 : Hopper

\section{B. Frame}

Frame was the structure that provide stability of the machine. The stability become a factor which can affect the quality of the grinder. Vibration on the machine also can affect the durability of the machine, because if the vibration is huge enough, there is a chance that the fastener become loose. The frame on this current machine was built using stainless steel. Stainless steel was chosen because stainless steel has a good strength to hold the weight of the other component and also very durable to corrosion. The frame design can be seen on Figure 2 


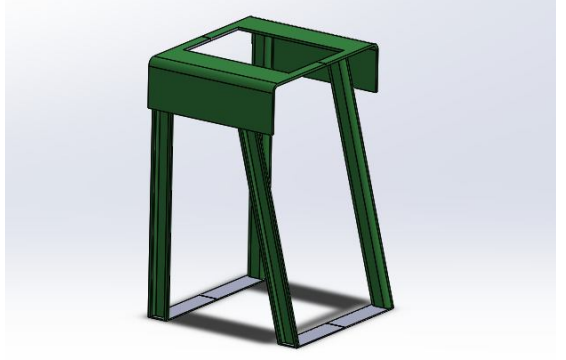

Figure 2 : Frame

\section{The Customized Disk}

Customized disk is the main factor of the quality of grinded coffee. The customized disk has an unique pattern to improve the quality of the grinding process. The customized disk also has the adjuster. The adjuster has the important role in the machine. The adjuster can set the preference of the output. On the front side of the disk, there 3 plate that have function to direct the coffee bean that missed the blade are. Not only to direct, the 3 plates also can crush the coffee bean into coarse grain the design of customized disk design can be seen on the Figure 3.

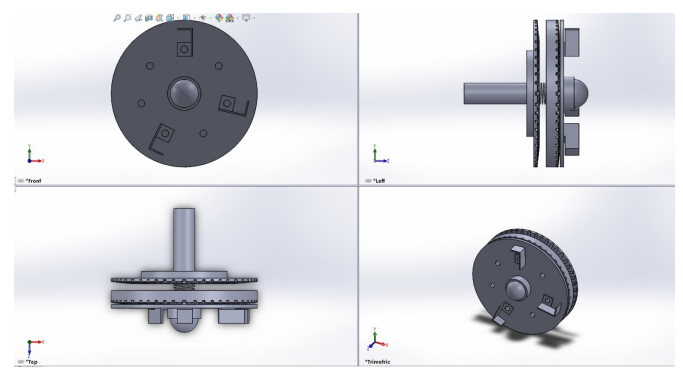

Figure 3 : Customized Disk

\section{Disk Housing}

The disk housing is a component where the coffee bean will get crushed in to the powder. The disk housing provided with the mesh component on its bottom. The mesh component has the function to filter the grain so only the fine grain can pass. The design of the disk housing can be seen on Figure 4

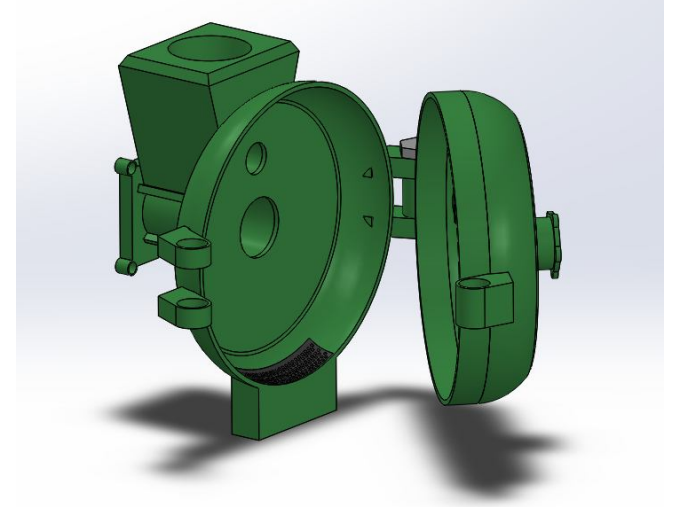

Figure 4 : Disk Housing

\section{E. Electric motor}

The electric motor become the main source of energy. The electric motor used to drive the disk mill. The electric motor will help to reduce the manpower to use the machine. The power that used on current electric motor is $1 \mathrm{HP}$. The design of the power motor can be seen on Figure 5.

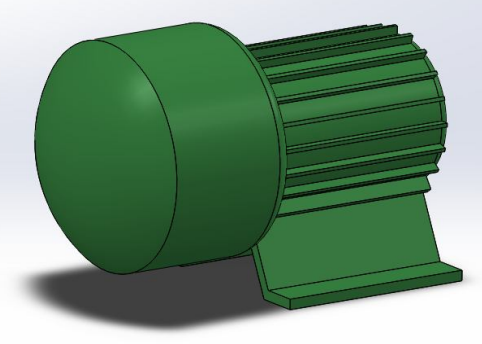

Figure 5 : Electric Motor

All of the component are assembled together to build the full machine. The assembly design of the full machine can be seen on the Figures 6. After the design process, the machine are then manufactured to realize the design. Figures 7 show the coffee grinder machine that has been fully manufactured. The manufacturing process use Stainless steel, aluminum, and plastic to build the component.

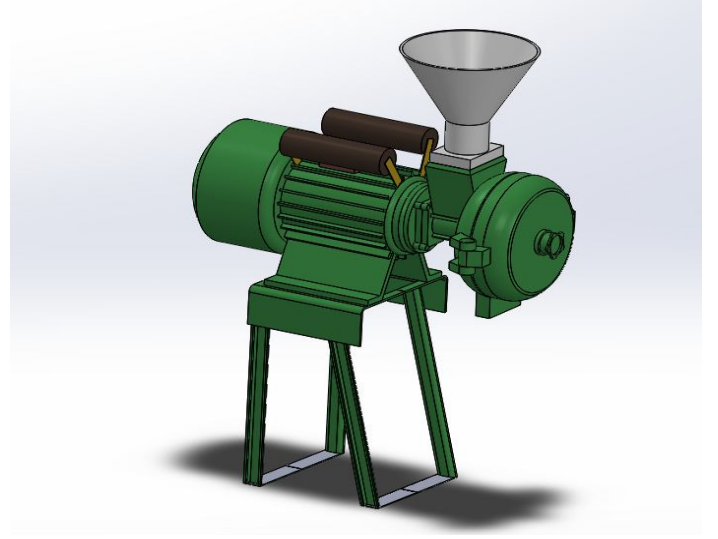

Figure 6 : The Assembly of grinding machine

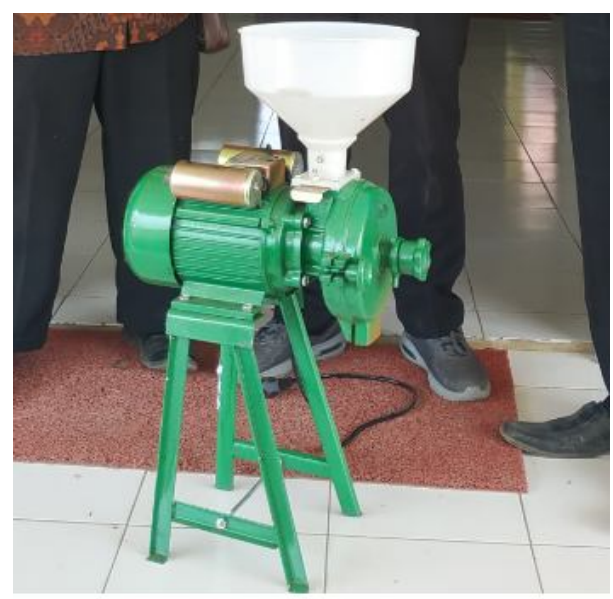

Figure 7 : The Prototype of grinding machine 
The focus of current research was to develop a machine that has production level above the common machine. Due to this goal, the performance analysis on this paper was only the production level of the current machine design compared to the production level on the common machine. The equation to calculate the production level can be seen below:

The formula to calculate production capacity per hour.

Production capacity per hour :

$$
\frac{\text { Total Weight Bean }}{\text { Total Time }} \times 3600
$$

Total weight bean means that the total bean that used in the experiment, this total weight bean and then divide with the total time needed for the machine to grind all of the bean into the powder. The result will be multiplied with 3600 which represent the duration of hour.

\section{RESULT AND DISCUSSION}

The test of the current coffee grinding machine took places in temanggung. The coffee bean that was used for the testing is an arabica varieties that grown on prau mountain with altitude off 1500 meter above sea level, further known as temanggung coffee. Figure 8 shows the grean been of the temanggung coffee, later the green bean will be roasted till medium dark. Figure 9 shows the temanggung coffee that has been roasted.

The amount of the coffee bean that used for the testing was splitted into 6 different size, 200 gr, 500 gr, 700 gr, 1000 gr, $2000 \mathrm{gr}$, and $3000 \mathrm{gr}$. The experiment also compared with the common machine. The common machine also have the same amount of the bean so the experiment can be apple to apple.

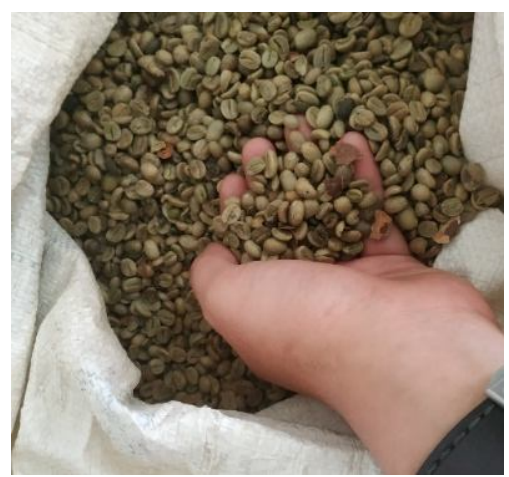

Figure 8 : green bean coffee before roasted

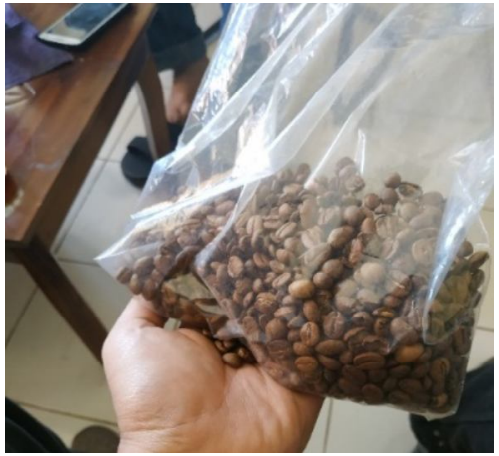

Figure 9 : Coffee bean that have been roasted

The result of the testing can be seen on Table 2. Table 2 show the comparison of the time between the common machine and the current machine. From the data, it can be seen that at 200 gr, the common machine needs 23 second and the current machine need 11 second to fully grind the bean till become flour. At $500 \mathrm{gr}$, the common machine needs $59 \mathrm{sec}$ of grinding time but also $600 \mathrm{sec}$ of resting time. The common machine needs to be rested after grinding $200 \mathrm{gr}$ of coffee due to the heat on the motor, the resting time itself take 5 minutes of minimum time. Different with the current machine, at 500 grams, the current machine can grind easily without resting and it takes $28 \mathrm{sec}$ to grind the coffee bean till become flour. At $700 \mathrm{gr}, 1000 \mathrm{gr}, 2000 \mathrm{gr}$, and $3000 \mathrm{grams}$, the common machine needs $84 \mathrm{sec}, 116 \mathrm{sec}, 219 \mathrm{sec}$, and $359 \mathrm{sec}$ of grinding time also $900 \mathrm{sec}, 1200 \mathrm{sec}, 2700 \mathrm{sec}, 4200 \mathrm{sec}$ of resting time, respectively. The current machine can achieve faster of both grinding time and the total time. The time of the current machine used to grind the coffee with the weight of $700 \mathrm{gr}, 1000 \mathrm{gr}, 2000 \mathrm{gr}$, and $3000 \mathrm{gr}$ are $42 \mathrm{sec}, 67 \mathrm{sec}, 118$ $\mathrm{sec}, 173 \mathrm{sec}$. The current machine doesn't need to rest because the capacity of the motor is good enough to drive the customized disk without resting.

Table 2 : The comparison of the time needed to grind the coffee. The time was sum between the grinding time and the resting time of the machine

\begin{tabular}{|c|c|c|c|c|}
\hline \multirow{2}{*}{ Weight } & \multicolumn{2}{|c|}{ Common Machine } & \multicolumn{2}{|c|}{ Current Design } \\
\hline & $\begin{array}{c}\text { Grinding } \\
\text { Time }\end{array}$ & $\begin{array}{c}\text { Resting } \\
\text { Time }\end{array}$ & $\begin{array}{l}\text { Grinding } \\
\text { Time }\end{array}$ & $\begin{array}{c}\text { Resting } \\
\text { Time }\end{array}$ \\
\hline 200 & 23 & 0 & 11 & 0 \\
\hline 500 & 59 & 600 & 28 & 0 \\
\hline 700 & 84 & 900 & 42 & 0 \\
\hline 1000 & 116 & 1200 & 67 & 0 \\
\hline 2000 & 219 & 2700 & 118 & 0 \\
\hline 3000 & 359 & 4200 & 173 & 0 \\
\hline
\end{tabular}




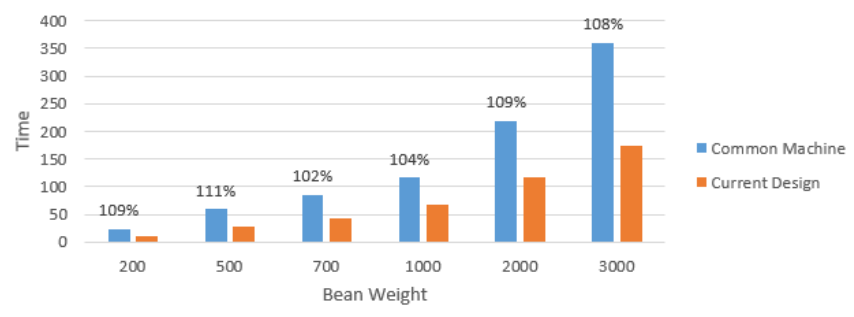

Figure 10 : Comparison of grinding time-only between the common machine and the current design

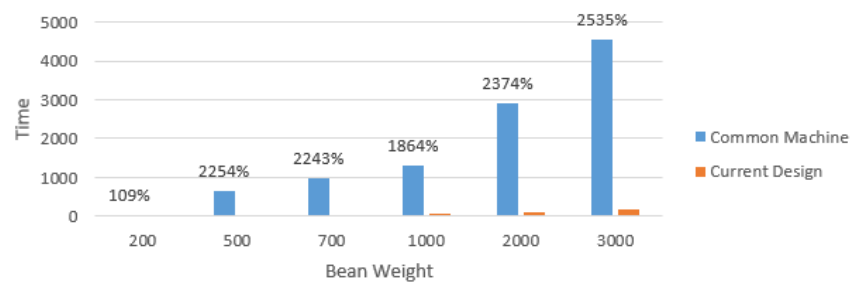

Figure 11 : The comparison of total time between the common machine and the current design

Figure 12 show the result of the coffee powder. Both machines produce the same quality of the coffee powder, this is because both machines can be adjusted to achieve same quality of the powder, whether it will be coarser or finer.

The production capacity of the machine also can be defined from the experiment. Using the equation (3):

Production capacity per hour:

$$
\begin{aligned}
& \frac{\text { Total Weight Bean }}{\text { Total Time }} \times 3600 \\
& \frac{6400}{4.39} \times 3600=52.482 \mathrm{gr}
\end{aligned}
$$

From the calculation, the production capacity of the current machine can achieve up to $52 \mathrm{~kg}$ per hour. With this production capacity, it can boost the production level of the coffee powder.

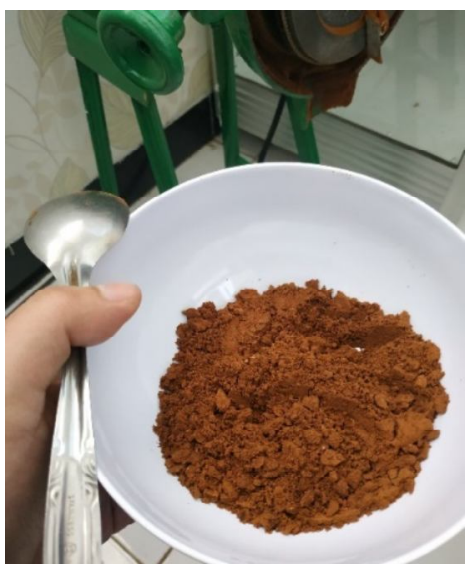

Figure 12 : The result of coffee powder

\section{CONCLUSION}

Based on the experimental results between the common machine and the current machine, it can be seen that the current machine can perform faster grinder with the same quality of the common machine. From the result, it can be seen that the common machine performs a slower grinding time, around $107 \%$ in average compared to the current machine. The total time to complete the process, the common machine takes lot of time compared to the current machine. This is because the common machine needs to be rested every $200 \mathrm{gr}$ of beans grinded, different with the current machine that does not need to rest. Using the current machine also can increase the production level, from the calculation, the current machine can boost the production level up to $52 \mathrm{~kg}$ per hour. The conclusion is, the current machine can achieve better production level but does not reduce the quality of the coffee powder.

\section{REFERENCES}

1. P. Stoffelen, M. Noirot, E. Couturon, and F. Anthony. A new caffeine-free coffee from Cameroon, Botanical Journal of the Linnean Society, vol. 158, no. 1, pp. 67-72, 2008.

2. C. A. Ogunlade, D. O. Aremu, O. A. Akinyele, N. A. Babajide. Design, Construction and Performance Evaluation of a Coffee (Coffea Arabica) Threshing Machine, International Journal of Engineering Research and Applications, vol. 4, pp. 56-64, 2014.

3. Suarez and Beaton. All about Coffee (2nd ed.), Gale Research, p. 725. ISBN 978- 0-8103-4092-3.

http://www.webbooks.com/Classics/ON/B0/B701/TOC. html . Retrieved January 12, 2003.

4. R. Oelviani, and A. Hermawan. Kebutuhan Teknologi Kopi di Jawa Tengah, Seminar Nasional BAPPEDA Provinsi Jawa Tengah, 2017.

5. Direktorat Jenderal Perkebunan. 2015. Peningkatan Produksi Dan Produktivitas Tanaman Rempah Dan Penyegar, Pedoman Teknis Tahun 2015 Pengembangan Tanaman Kopi Berkelanjutan, Ditjend Perkebunan, 2015.

6. MT. HS, S. Raharto, and T. Agustina. Prospek Pengembangan Komoditas Kopi Robusta Di Pt. Kaliputih Kecamatan Ledokombo Kabupaten Jember, JSEP (Journal of Social and Agricultural Economics), vol. 8, no. 2, pp. 11-24, 2015.

7. N. Hanani, R. Asmara, and F. Fahriyah. Persaingan Ekspor Kopi Indonesia di Pasar International, Perhimpunan Ekonomi Pertanian Indonesia, 2012.

8. Y. X. Zhu, W. Chen, H. P. Li, Y. L. Liu, L. Chen. Springback study of RDB of rectangular $\mathrm{H96}$ tube. International Journal of Mechanical Sciences, vol. 138, pp. 282-294, 2018. doi:https://doi.org/10.1016/j.ijmecsci.2018.02.022

9. Dioses, J.L. Discrimination of civet coffee using image processing and machine learning, International 
Vivi Endar Herawati et al., International Journal of Emerging Trends in Engineering Research, 8(7), July 2020, 4806 - 4811

Journal of Emerging Trends in Engineering Research 8(4),19, pp. 1067-1072, 2020.

https://doi.org/10.30534/ijeter/2020/19842020

10. Bestley Joe, S., Ramadevi, R., Amala Rani, V., Rajalakshmi, G. Automatic cooking machine using Arduino, International Journal of Emerging Trends in Engineering Research 8(1), pp. 35-40, 2020.

https://doi.org/10.30534/ijeter/2020/07812020 